\title{
Investigation of Antioxidant and Cytotoxic Effects of Biotechnologically Produced Carotenoids from Rhodobacter sphaeroides O.U. 001
}

\author{
Rhodobacter sphaeroides O.U.001'den Biyoteknolojik Olarak Üretilen Karotenoidlerin \\ Antioksidan ve Sitotoksik Etkilerinin Araştırılması
}

\author{
Gökhan KARS ${ }^{* 1, a}$, Meltem DEMİREL KARS ${ }^{2, b}$, İhsan OBALI ${ }^{3, \mathrm{c}}$, Ayça EMSEN $^{4, \mathrm{~d}}$, Ufuk GÜNDÜZ ${ }^{5, \mathrm{e}}$ \\ ${ }^{I}$ Necmettin Erbakan University, Faculty of Science, Department of Molecular Biology and Genetics, Konya \\ ${ }^{2}$ Necmettin Erbakan University, Meram Vocational School, Medicinal and Aromatic Plants Program, Konya \\ ${ }^{3}$ Selçuk University, Faculty of Science, Department of Biology, Konya \\ ${ }^{4}$ Selçuk University, Faculty of Medicine, Department of Pediatric Immunology, Konya \\ ${ }^{5}$ Middle East Technical University, Department of Biological Sciences, Ankara
}

\begin{abstract}
Carotenoids take special attention due to their strong antioxidant properties. In the present study, the antioxidant and antiproliferative effects of carotenoids extracted from Rhodobacter sphaeroides O.U. 001 were investigated. For this, $R$. sphaeroides O.U. 001 was first cultivated in a $5 \mathrm{~L}$ bioreactor. After that, the carotenoids were extracted from $R$. sphaeroides O.U. 001 using acetone as solvent. The effects of carotenoid extract on proliferation of vincristine and paclitaxel resistant cells (MCF-7/Vinc, MCF-7/Pac) were investigated by MTT cytotoxicity assay. The checkerboard plate technique was performed to evaluate the interactions between carotenoid extract and cancer drugs on the cells. The antioxidant activity of the carotenoid extract was assessed by 2, 2 - diphenyl, 1- picryl hydrazyl (DPPH) radical scavenging assay. As a result of extraction, considerable amount of carotenoid yield was obtained (80.69 mg carotenoid/g dry cell weight). It was found that carotenoid extract had no inhibitory effects on cell proliferation and interaction of carotenoids with anticancer drugs exhibited antagonistic effects. In addition to these, the DPPH antioxidant activity ( $\mathrm{IC}_{50}$ value) of the carotenoid extract was calculated as $25 \mu \mathrm{g} / \mathrm{mL}$. In conclusion, biotechnologically produced bacterial carotenoids were shown to have considerable antioxidant activity without any cytotoxicity on cancer cells.
\end{abstract}

Keywords: Antioxidant, Bioreactor, Carotenoid, MCF-7, Rhodobacter sphaeroides

\section{$\ddot{O} z$}

Karotenoidler güçlü antioksidan özelliklerinden dolayı dikkat çekmektedirler. Bu çalışmada, Rhodobacter sphaeroides O.U. 001'den ekstrakte edilen karotenoidlerin antioksidan ve antiproliferatif etkileri araştırıldi. Bunun için, R. sphaeroides O.U. 001 önce 5 L'lik bir biyoreaktörde çoğaltıldı. Daha sonra, çözücü olarak aseton kullanılarak R. sphaeroides O.U.001'den karotenoidler ekstrakte edildi. Karotenoid ekstraktının, vinkristin ve paklitaksele dirençli hücrelerin (MCF-7/Vinc, MCF-7/Pac) proliferasyonuna etkileri MTT sitotoksisite testi ile araştırlld. Karotenoid ekstraktı ve kanser ilaçları arasındaki etkileşimin hücreler üzerindeki etkisi dama tahtası plaka tekniği ile değerlendirildi. Karotenoid ekstraktın antioksidan aktivitesi ise 2, 2 - difenil, 1-pikril hidrazil (DPPH) radikal süpürücü aktivite tayin yöntemi ile belirlendi. Ekstraksiyon sonucunda, önemli miktarda karotenoid verimi elde edildi (80.69 mg karotenoid/g kuru hücre ă̆ırlı̆̆l). Karotenoid ekstraktının hücre proliferasyonu üzerinde inhibitör etkisinin olmadı̆̆l ve antikanser ilaçlarla etkileşiminin antagonistik olduğu bulundu. Bunlara ek olarak, elde edilen karotenoid ekstraktının DPPH antioksidan etkisi, (IC 50 değeri) $25 \mu \mathrm{g} / \mathrm{mL}$ olarak hesaplandl. Sonuç olarak, biyoteknolojik yolla üretilen bakteriyel karotenoidlerin, kanser hücrelerinde sitotoksik etki göstermeden önemli antioksidan aktiviteye sahip olduklarl gösterilmiştir.

Anahtar Kelimeler: Antioksidan, Biyoreaktör, Karotenoid, MCF-7, Rhodobacter sphaeroides

\footnotetext{
*a Gökhan KARS; gkars@erbakan.edu.tr, Tel: (0332) 32382 20; orcid.org/0000-0002-2507-2305

${ }^{\mathrm{b}}$ orcid.org/0000-0002-7300-4075

c orcid.org/0000-0002-6090-1981

${ }^{\mathrm{d}}$ orcid.org/0000-0003-3028-3112

e orcid.org/0000-0002-5158-7652
} 


\section{Introduction}

Purple non-sulfur bacteria (PNS), a group of photosynthetic bacteria, have rich metabolic activities. They can exhibit aerobic, anaerobic, photosynthetic or fermentative reproduction patterns. Due to these properties, purple nonsulfur bacteria are used to study metabolic pathways like nitrogen and carbon fixation, oxygen-free photosynthesis and membrane bioenergy (Joshi and Tabiata, 1996; Oelze and Klein, 1996; Kars and Gündüz, 2010). Furthermore, PNS bacteria have many biotechnological applications. For instance, many high-value-added metabolic products like 5-aminolevulinic acid, biohydrogen, coenzyme Q10, poly- $\beta$-hydroxybutyrate, vitamin B12 and carotenoid can be produced by them simultaneously (Sasaki et al., 2005; Kars and Gündüz, 2010). Among PNS bacteria, strains of Rhodobacter sphaeroides take special attention due their wide range of metabolic activities and many primary and secondary metabolites. One of the attractive properties of $R$. sphaeroides is that it is non-pathogenic and it does not induce any systemic immune reaction (Takayama et al., 1989; Kwon et al., 2014). For this reason, $R$. sphaeroides as a robust and sustainable cell factory has attracted attention in many biotechnological and medical applications. Another attractive property of $R$. sphaeroides is that it can utilize a wide variety of feedstocks like industrial wastes or by-products as substrate which in turn increases the feasibility and costeffectiveness of the production process. The last but not the least, $R$. sphaeroides is a unique model for the production of more than one product at a time in the same bioprocess through valorization of wastes or by-products. In this way, $R$. sphaeroides could be a part of the biorefirnery application where several valuable products like biofuels and chemicals are produced by maximizing the benefit from biomass (Menon and Rao, 2012). Due to these features, non-pathogenic $R$. sphaeroides was selected as a source microorganism in the present study.

Carotenoids are lipophilic pigments which could be red, yellow, orange and purple in color and have essential roles in photosynthesis (Fraser et al., 2001). First, they are functional as a light absorbing pigment by absorbing and transferring light energy to be used in photosynthesis. Second, they have a photoprotective role. They perform this function by either quenching the excited bacteriochlorophylls and thereby preventing the formation of singlet oxygen or quenching directly the preformed singlet oxygen. Finally, they act as structural element in light harvesting complex. Due to their intrinsic feature, they have strong antioxidant property. The production of carotenoids could be achieved in several ways such as chemical synthesis, extraction from plants or microorganisms and production from industrial wastes. Although synthetic production process costs low, it requires complex steps and the products generally consist of chemical byproducts and isomers which could be harmful. Hence, such a process is not ecologically and medically favorable. On the other hand, natural pigments generally do not have side effects and their production processes are cost efficient. Although, production of carotenoids from biological sources is advantageous, current production techniques need to be enhanced so as to produce high amount of carotenoids in efficient bioprocesses. In this context, overproduction of carotenoids through metabolic engineering of microorganisms is among the mostly applied strategies. This was generally achieved by reorganizing the genes to utilize much of the carbon flux, metabolites, cofactors and reducing equivalents for the biosynthesis of carotenoids in the cells ( $\mathrm{Li}$ et al., 2020). Besides, various carotenoid extraction techniques and solvent-solid ratios were tested to obtain high carotenoid yields ( $\mathrm{Gu}$ et al., 2008; Saini and Keum, 2018). For instance, Gu et al. (2008) tested three different carotenoid extraction methods namely ultrasonic assisting, grinding and $\mathrm{HCl}$ assisting and $\mathrm{HCl}$ assisting extraction was found to be most effective one. Still, there are factors like temperature and extraction time which contribute to the overall carotenoid production efficiency. The use of sustainable and cheap feedstocks may also help to increase the costefficiency of the carotenoid production process.

Approximately, 2-3\% of the cell dry weight of $R$. sphaeroides is constituted by carotenoids named as spheroidene and spheroidenone (Figure 1) (Lang et al., 1995; Yeliseev et al., 1996; Gu et al., 2008). Photosynthetic elements including carotenoids are located in the intracytoplasmic membrane (ICM) of $R$. sphaeroides. The structural characterization and biosynthetic metabolism of the carotenoids have already been revealed (Shneour, 1962; Armstrong, 1994). $R$. sphaeroides was cultured under different conditions (semi-aerobic, photosynthetic and Dark/DMSO) and then extraction, quantification and characterization of the carotenoids were performed (Yeliseev et al., 1996). It was found out that the relative amount of spheroidene was about $76 \%$ under photosynthetic conditions while the relative amount of spheroidenone was $96 \%$ 
under semi-aerobic conditions. Interestingly, higher rate of spheroidene (circa 85\%) was obtained in case the cells were harvested under anoxic conditions without light using dimethyl sulfoxide (DMSO) as terminal electron acceptor. The aforementioned studies provided sufficient knowledge about the structure and composition of bacterial carotenoids. Therefore, from this point on, the progresses on biotechnological production and applications of carotenoids need to be achieved. Specifically, various sustainable and cheap feedstocks need to be tested to achieve low cost bioprocesses in addition to effective carotenoid extraction procedures. In addition, the potential applications of carotenoids should be explored in different fields.

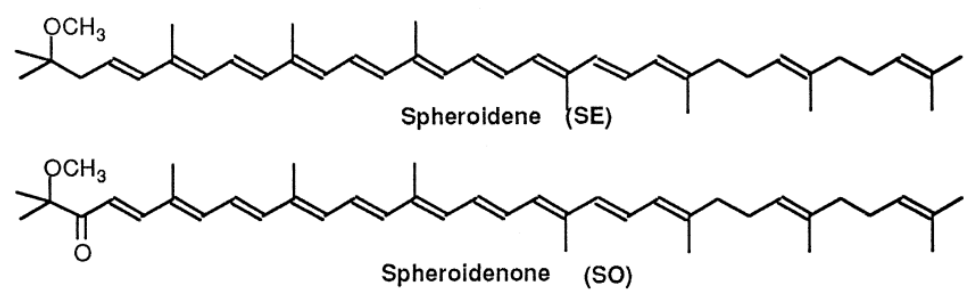

Figure 1. The carotenoids in R. sphaeroides (Yeliseev and Kaplan, 1997).

It was shown that natural compounds like carotenoids and phenolic compounds produced by plants and microorganisms were effectively used in the treatment of cancer and other illnesses (Saklani and Kutty, 2008; Gu et al., 2008). Specifically, different natural and synthetic products obtained from plants, microorganisms and different derivatives have been tested on various cancer cells in terms of the capacities of drug resistance reversing activities (Molnár et al., 2004; Fong et al., 2007), in addition to their antiproliferative efficacy (Ugocsai et al., 2005; Kars et al., 2008). Cancer cells develop resistance to chemotherapeutics due to drug efflux through Pglycoprotein which is produced by multiple drug resistance 1 gene (O'driscoll and Clynes, 2006). Scientist intensively made research to overcome multi drug resistance (MDR) and to inhibit $\mathrm{ABC}$ transporters (ATP binding cassette transporters). Natural carotenoids might have the potency to be utilized as either anti-cancer agents or as antioxidant in preventive or prophylactic treatments.

In this study, motivated from the aforementioned arguments, production of bacterial carotenoids in a cost-effective bioprocess using a sustainable and cheap feedstock and their biotechnological and medical applications were investigated. For this, $R$. sphaeroides was first cultivated in a $5 \mathrm{~L}$ bioreactor utilizing sugar beet molasses as a costefficient substrate prior to the extraction of carotenoids. As substrate, molasses which was produced in a local sugar factory was used. This increases the sustainability of the carotenoid production process and contributes to the circular economy. To our knowledge, this is the first that
$R$. sphaeroides was cultured in a $5 \mathrm{~L}$ bioreactor using locally produced molasses for carotenoid extraction in Turkey. Then, toxicological and antioxidant effects of carotenoids on drug (paclitaxel and vincristine) sensitive and resistant mammary cancer cells were evaluated. These drug resistant cells were also used for the first time in the literature for the toxicity assessment of carotenoid extracted from $R$. sphaeroides. It was demonstrated that carotenoid extract had a significant free radical scavenging capacity in comparison with L-ascorbic acid, which could be considered as reference antioxidant. And, carotenoid extract had no inhibitory effects on cell proliferation. Based on these findings, it can be proposed that $R$. sphaeroides could successfully be cultivated in cost-efficient bioprocesses using sustainable and cheap biomass like molasses and the bacterium can potentially be used as a promising natural source for carotenoids to be used as antioxidant in medical applications.

\section{Materials and Methods}

\subsection{Cultivation of R. sphaeroides in Bioreactor and Total Carotenoid Extraction}

As a source of bacterial carotenoid, $R$. sphaeroides O.U. 001 (DSM 5864) was used. Sugar beet molasses (SBM) provided from a sugar factory (Konya Şeker, Turkey) was utilized as substrate. It contains circa 50\% (w/w) sucrose in addition several elements ( $\mathrm{K}, \mathrm{Na}, \mathrm{Mg}, \mathrm{Ca}, \mathrm{Al}, \mathrm{Mo}$, $\mathrm{Zn}, \mathrm{Cu}, \mathrm{Ni}, \mathrm{Co}, \mathrm{Fe}, \mathrm{Mn}, \mathrm{Cr}$ and $\mathrm{B}$ ) and organic acids (Succinic acid, Fumaric acid, Malic acid, Propionic acid, Acetic acid, Lactic acid and Formic acid) in considerable amounts. The 
detailed compositional analysis of molasses was performed and the best molasses concentration was determined in a previous study (Kars and Alparslan, 2013). Based on these early findings, $28 \mathrm{~g} / \mathrm{L}$ sucrose was used as the optimum concentration for cell growth in the present study. To culture the bacteria, $3150 \mathrm{~mL}$ of medium containing $55 \mathrm{~g} / \mathrm{L}$ SBM (circa $28 \mathrm{~g} / \mathrm{L}$ sucrose) was prepared by dispensing $173.25 \mathrm{~g}$ of molasses in water. The suspension was centrifuged at $9418 x g$ for $10 \mathrm{~min}$. to precipitate the debris so that a transparent medium was obtained. Then, $\mathrm{KH}_{2} \mathrm{PO}_{4}$ (1.575 g), $\mathrm{MgSO}_{4} \cdot 7 \mathrm{H}_{2} \mathrm{O}(0.63 \mathrm{~g}), \mathrm{CaCl}_{2} \cdot 2 \mathrm{H}_{2} \mathrm{O}$ $(0.1575 \mathrm{~g}), \mathrm{Na}$ Glutamate $(1.1655 \mathrm{~g}), \mathrm{FeSO}_{4}$ $(0.0063 \mathrm{~g})$ and $\mathrm{Na}_{2} \mathrm{MoO}_{4} \cdot 2 \mathrm{H}_{2} \mathrm{O}(0.0126 \mathrm{~g})$ were added into the medium at given quantities. The $\mathrm{pH}$ of the medium was set to 6.8. After that the whole media was transferred into the bioreactor vessel and the bioreactor was placed into autoclave for sterilization. After cooling the bioreactor to room temperature, $315 \mu \mathrm{L}$ of vitamin solution (Biotin, $15 \mathrm{mg} / \mathrm{L}$; Niacin, $500 \mathrm{mg} / \mathrm{L}$; Thiamine, $500 \mathrm{mg} / \mathrm{L}$ ) was added into the vessel through one of the ports under sterile conditions. From this point, the bioreactor vessel inlets were tightly sealed and isolated in order not to let any air go into the vessel and contaminate the medium.

In the present study, Sartorius BIOSTAT ${ }^{\circledR}$ B plus bioreactor (5L, UniVessel ${ }^{\circledR}$ Glass) was used and the bioreactor was operated at batch mode, (Figure 2). $70 \%$ of the total volume $(5 \mathrm{~L})$ was used as working volume. The bioreactor was inoculated with $350 \mathrm{~mL}$ of pre-cultured actively growing cells and the anaerobic condition was assured by passing argon gas through the bioreactor for $3 \mathrm{~min}$. Although there is no need to agitate the culture since $R$. sphaeroides has flagella for movement and bioreactor was operated under anaerobic atmosphere, the culture was stirred by the impeller inside the vessel at 140 rpm to allow the cells to benefit more from the light. The temperature was kept at $28{ }^{\circ} \mathrm{C}$ by the water supplied from the chiller unit (Sartorius stedim FRIGOMIX $\left.{ }^{\circledR} 1000\right)$ to the glass heating/cooling jacket that surrounds the vessel. The culture was incubated under the illumination of incandescent lamps (775 \pm 25 lux $)$. The turbidity of the culture was measured in certain time intervals and the process was run until the OD of the sample culture was 1.55 at $660 \mathrm{~nm}$. Then, the cells were harvested for carotenoid extraction.

The carotenoid isolation procedure was adapted from (Gu et al., 2008). The bacterial culture was divided into separate tubes and centrifuged at $9418 \mathrm{xg}$ for $20 \mathrm{~min}$. The pellets were washed, collected in one tube and re-centrifuged. The pellets were collected in a beaker and freezed at $80^{\circ} \mathrm{C}$ overnight. The freezed pellet was lyophilized at $-111^{\circ} \mathrm{C}$ under 0.009 mbar. The freeze-dried biomass was weighed, suspended in $240 \mathrm{~mL}$ of $3 \mathrm{M} \mathrm{HCl}$ and disrupted by shaking at $100 \mathrm{rpm}$ for half an hour at $28^{\circ} \mathrm{C}$. The hydrolysate was centrifuged at $9418 \mathrm{xg}$ for $20 \mathrm{~min}$. and supernatant containing carotenoids was transferred to a new tube. Solvent was evaporated by rotary evaporator $\left(\right.$ at $37^{\circ} \mathrm{C}$ ) and remaining part was lyophilized. The amount of bacterial carotenoid was calculated by measuring the absorbance (at $480 \mathrm{~nm}$ ) of carotenoid suspension and then using this value in the formula together with conversion factors. The below equation was used to calculate carotenoid yield and concentration, where A is absorbance (at $480 \mathrm{~nm}$ ), $\mathrm{D}$ is dilution factor, $\mathrm{V}$ is solvent volume $(\mathrm{mL})$ and $\mathrm{W}$ is bacteria dry weight ( $\mathrm{g}$ ) ( $\mathrm{Gu}$ et al., 2008; Carvalho et al., 2012; Zhao et al., 2019).

Carotenoid yield $\left(\frac{\mu g}{g}\right)=\frac{1000 \times A \times D \times V}{0.16 \times W}$

\subsection{Cell Lines and Determination of the Effects of Carotenoid Extract on Cancer Cells}

Paclitaxel and vincristine (anticancer drugs) resistant mammary carcinoma cell lines were used as reference cell lines for drug resistant breast cancer (Kars et al., 2008). The drug resistant cells lines were previously established from breast cancer cell line MCF-7. The drug resistant cells were selected from the cell culture medium by increasing the treatment doses of paclitaxel and vincristine. The effects of carotenoid extract on the proliferations of paclitaxel and vincristine resistant MCF-7 cells were evaluated in 96-well microplate as performed previously (Kars et al., 2008). Extract was diluted from $10 \mathrm{mg} / \mathrm{mL}$ to 0.02 $\mathrm{mg} / \mathrm{mL}$ horizontally in the plates. 10,000 cells were inoculated into each well. $\mathrm{IC}_{50}$ values of paclitaxel and vincristine on the cells were used for comparison. The effect of carotenoid extract dilutions on cell proliferation and $\mathrm{IC}_{50}$ values were calculated through cell proliferation graphics. The checkerboard plate technique was performed to evaluate the interactions between carotenoid extract and cancer drugs on the cells. The microtubule inhibitors (paclitaxel, vincristine) were diluted horizontally from left to right and carotenoid extract was diluted from up to down in vertical direction in a 96 well microplate (drugs and extract was diluted 1:2 serially starting from 
$\mathrm{IC}_{50}$ values). 10,000 cells were inoculated into the wells. Inhibitory concentration for each combination was calculated with respect to nodrug control wells. The fractional inhibitory index (FIX) value was calculated and if the value was in between 0.51 and 1.00, the interaction was stated to be additive; if the value was lower than 0.50 , the interaction was told to be synergistic; and if the FIX was higher than 2, it meant the interaction was antagonistic (Kars et al., 2008).

\subsection{Determination of Antioxidant Activity of Bacterial Carotenoid Extract}

2,2-diphenyl-1-picrylhydrazyl (DPPH) scavenges labile protons from antioxidants with further generation of hydrazine without any color (Diouf et al., 2009). Carotenoid extract from $R$. sphaeroides was prepared as $2.08 \mathrm{mg} / \mathrm{mL}$ concentration in methanol. The extract was diluted in range of $208 \mu \mathrm{g} / \mathrm{mL}-4.06 \mu \mathrm{g} / \mathrm{mL}$. Lascorbic acid (Sigma) was used as positive control. Ascorbic acid was diluted from 200 $\mu \mathrm{g} / \mathrm{mL}$ to $0.39 \mu \mathrm{g} / \mathrm{mL}$ and then $20 \mu \mathrm{g} / \mathrm{mL}$ DPPH solution was added to the carotenoid and ascorbic acid wells in 3:1 ratio. After $30 \mathrm{~min}$. incubation at room temperature in dark, the measurement of the optical density at $517 \mathrm{~nm}$ was performed. Free radical clearance effect of bacterial carotenoids was determined by using the blank solution (DPPH in solvent) as the highest free radical containing solution, $100 \%$ numerically. The free radical scavenging activity (FRSA) of the extract was demonstrated as the quantity of carotenoid extract which alleviate DPPH activity by $50 \%$ $\left(\mathrm{IC}_{50}\right)$. The FRSA of carotenoid extract was calculated from the equation of the logarithmic best line of the graph drawn as DPPH \% inhibition vs. carotenoid extract concentration $(\mathrm{mg} / \mathrm{mL})$. The assay was performed as triplicates.

\subsection{Statistics}

The results of cell proliferation tests and DPPH assay were subjected to t-test to compare the difference between groups or treatments (SPSS, $\mathrm{p}<0.05$ ).

\section{Result and Discussions}

\subsection{Total Carotenoid Extraction from $R$. sphaeroides Grown in 5 Liter Bioreactor}

Due to the intrinsic features of $R$. sphaeroides' carotenoids, they have substantial potential to be used as antioxidants by effectively neutralizing singlet oxygen species in the surroundings. In addition, $R$. sphaeroides' being non-immunogenic and non-pathogenic makes it a valuable source of carotenoids. There are two possible ways to enhance bacterial carotenoid production. Either recombinant DNA technology could be applied or culture conditions could be adjusted to obtain higher carotenoid amount. The genetic methods for $R$. sphaeroides are well established but gene manipulations require significant efforts and there are many targets to be improved. In this regard, in the present study, optimum culture conditions were applied for enhanced cell growth and carotenoid production based on previous experiences and literature findings. It was observed in previous studies that sugar beet molasses supported the proliferation of $R$. sphaeroides significantly (Kars and Alparslan, 2013). The maximum cell density (OD660: 8.3) was attained in a medium which contained sugar at a concentration of $28 \mathrm{~g} / \mathrm{L}$. This cell density is the highest value that has been obtained so far. Based on this result, $R$. sphaeroides was cultivated in medium prepared by using sugar beet molasses at aforementioned concentration. Sugar beet molasses which was produced in Konya was used as substrate for carotenoid production in this study. Thus, valorization of locally produced molasses was realized by producing valuable pigments. Taking into account previous experiences and literature findings, the cells were cultured in $5 \mathrm{~L}$ bioreactor for the production of carotenoids. The bioprocess was operated in batch mode using $5 \mathrm{~L}$ bioreactor. Upon harvesting the cells, $5.8 \mathrm{~g}$ of bacteria dry weight was obtained. The carotenoids were extracted from dry cells using acetone as solvent. An optical density of 0.039 was obtained after 8 times dilutions at 480 $\mathrm{nm}$. Taking into account the dilution factor and solvent volume $(240 \mathrm{~mL})$, the carotenoid yield was calculated as $80.69 \mathrm{mg} / \mathrm{g}$ (carotenoid/dry biomass). This value corresponds to circa $8 \%$ $(w / w)$ of the cell dry weight. In addition, the concentration of total carotenoids was calculated as $133.71 \mathrm{mg} / \mathrm{L}$. In Table 1 , examples of carotenoid yields obtained from organisms using different substrates were listed. As it is seen from the Table 1, the highest carotenoid yield (80.69 $\mathrm{mg} / \mathrm{g}$ ) was obtained from $R$. sphaeroides. There could be several explanations for this high carotenoid yield. First, molasses may have had a promoting effect on the synthesis of carotenoid since molasses was found to support growth and metabolism of the bacteria substantially and very high cell densities were attained using molasses when compared to other carbon source like malate and acetate (Kars et al., 2009; Kars and Alparslan, 2013). Second, due to dark color of the molasses 
and therefore the dark color of the media, the bacteria may have had limited access to light. To overcome this, the cells may have synthesized more carotenoid to collect more light. The shading effect of high cell density may have contributed to this high yield, as well. In parallel with these discussions, low light intensity and high cell density have been reported to significantly increase the relative content of bacteriochlorophyll and carotenoid in $R$. sphaeroides 2.4.1 (Yeliseev et al., 1996). To sum up, using molasses under limited light conditions could be the reason for such a high carotenoid yield.

Table 1. The examples of carotenoid yield from different organisms

\begin{tabular}{|c|c|c|c|}
\hline Organism & C source & $\begin{array}{c}\text { Yield } \\
\text { (mg/g dry } \\
\text { weight) }\end{array}$ & Reference \\
\hline $\begin{array}{c}\text { Rhodobacter sphaeroides } \\
\text { O.U. } 001\end{array}$ & SBM sucrose $(28 \mathrm{~g} / \mathrm{L})$ & 80.69 & This study \\
\hline Rhodobacter sphaeroides & $\begin{array}{c}\text { Citric acid }(8.1 \mathrm{~g} / \mathrm{L}), \text { corn syrup } \\
(1.8 \mathrm{~g} / \mathrm{L})\end{array}$ & 4.650 & (Gu et al., 2008) \\
\hline $\begin{array}{l}\text { Rhodotorula mucilaginosa } \\
\text { (NRRL-2502) }\end{array}$ & Whey lactose $(13.2 \mathrm{~g} / \mathrm{L})$ & 35.00 & $\begin{array}{l}\text { (Aksu and Eren, } \\
\text { 2005) }\end{array}$ \\
\hline $\begin{array}{l}\text { Rhodotorula glutinis } \\
\text { (CCT 2186) }\end{array}$ & $\begin{array}{l}\text { Sugar cane sugar }(2.88 \mathrm{~g} / \mathrm{L}) \text {, yeast } \\
\text { extract }(10 \mathrm{~g} / \mathrm{L}) \text {, peptone }(10 \mathrm{~g} / \mathrm{L})\end{array}$ & 0.197 & (Squina et al., 2002) \\
\hline Rhodotorula rubra & $\begin{array}{l}\text { Sugar cane sugar }(2.88 \mathrm{~g} / \mathrm{L}) \text {, yeast } \\
\text { extract }(10 \mathrm{~g} / \mathrm{L}) \text {, peptone }(10 \mathrm{~g} / \mathrm{L})\end{array}$ & 0.426 & (Squina et al., 2002) \\
\hline Nannochloropsis gaditana & Autotrophy & 0.343 & $\begin{array}{c}\text { (Macias-Sanchez et } \\
\text { al., 2005) }\end{array}$ \\
\hline Rhodotorula rubra & Glucose $(18.75 \mathrm{~g} / \mathrm{L})$ & 8.352 & $\begin{array}{c}\text { (Varmira et al., } \\
\text { 2018) }\end{array}$ \\
\hline
\end{tabular}

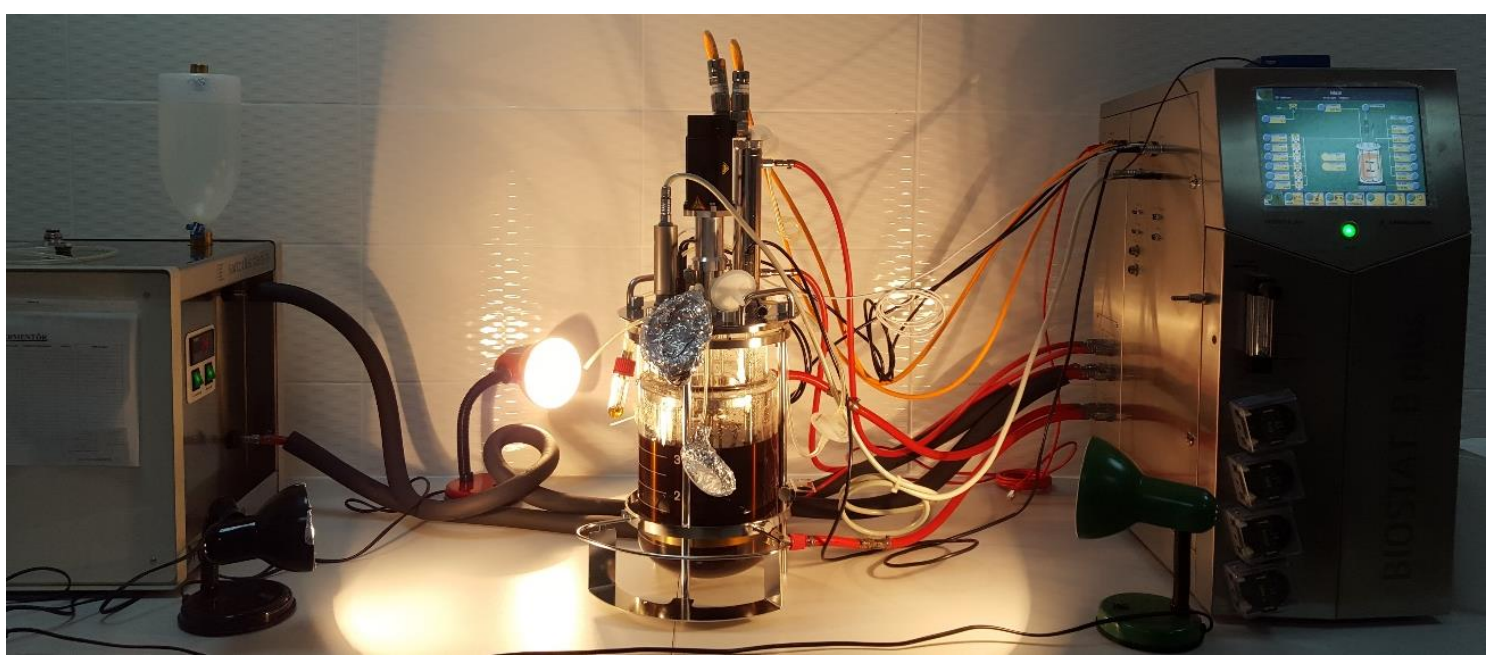

Figure 2. The bioreactor configuration used for cultivation of $R$. sphaeroides

\subsection{Effects of Bacterial Carotenoids on Breast Cancer Model Cells}

Carotenoid extract was applied to the MCF-7 cell lines and it was found that bacteria carotenoid extract did not inhibit the proliferation of cells. In addition to this, the resistant cells were also resistant to the carotenoid extract about three folds. In other words, three folds more carotenoid extract was required to diminish cell viability to fifty percent for resistant cells (Table 2, Figure 3).
Regarding MDR reversal agents, high toxicity is the most important problem (Wong et al., 2009; Teg et al., 2016). For this reason, studies on the detection of safe, non-toxic MDR modulators are important. When the interaction of extract with paclitaxel and vincristine was considered, it was concluded that carotenoid extract did not act synergistically with anticancer agents. The carotenoid extract dilutions equal and lower than its $\mathrm{IC}_{50}$ concentrations exhibited antagonistic effects compared to the microtubule inhibitor 
drugs paclitaxel and vincristine (Table 3). This antagonism may have been resulted from the dilution of the effects of anticancer drugs by nontoxic extract solution. Previously, carotenoids were exhibited as MDR modulating agents in several studies. It was shown that beta carotene might be proposed as an MDR modulator and was a good candidate to be used in adjuvant therapy in drug resistant cancer cases (Teng et al., 2016). It was also claimed that semi-beta carotene-epoxide has higher MDR reversal activity than verapamila known MDR blocker (Molnar et al., 2009). So, the fact that the $R$. sphaeroides carotenoid extract has no antiproliferative effect on the drug resistant cells opens the possibility of using this extract as drug resistance modulator in future studies. Drug resistance reversal capacity of bacterial carotenoids needs to be investigated by revealing the interaction of extract with P-glycoprotein, the MDR responsible protein.

Table 2. $\mathrm{IC}_{50}$ values obtained from cytotoxicity tests.

\begin{tabular}{lll}
\hline MCF-7 Cells & Drug/extract & $\begin{array}{l}\mathbf{I C}_{\mathbf{5 0}}(\mathbf{m g} / \mathbf{m L}) \\
\mathbf{\mathbf { S D }}(\boldsymbol{p}<\mathbf{0 . 0 5})\end{array}$ \\
\hline Drug sensitive & Paclitaxel & $0.002 \pm 0.0002$ \\
& Vincristine & $0.005 \pm 0.0006$ \\
& $\begin{array}{l}\text { Carotenoid } \\
\text { extract }\end{array}$ & $0.21 \pm 0.01$ \\
\hline $\begin{array}{l}\text { Paclitaxel } \\
\text { resistant }\end{array}$ & Paclitaxel & $0.27 \pm 0.0002$ \\
& Carotenoid & $0.65 \pm 0.09$ \\
\hline $\begin{array}{l}\text { Vincristine } \\
\text { resistant }\end{array}$ & Vincristine & $0.10 \pm 0.002$ \\
& Carotenoid & $0.57 \pm 0.06$ \\
& extract & \\
\hline
\end{tabular}

Table 3. Extract-drug interactions

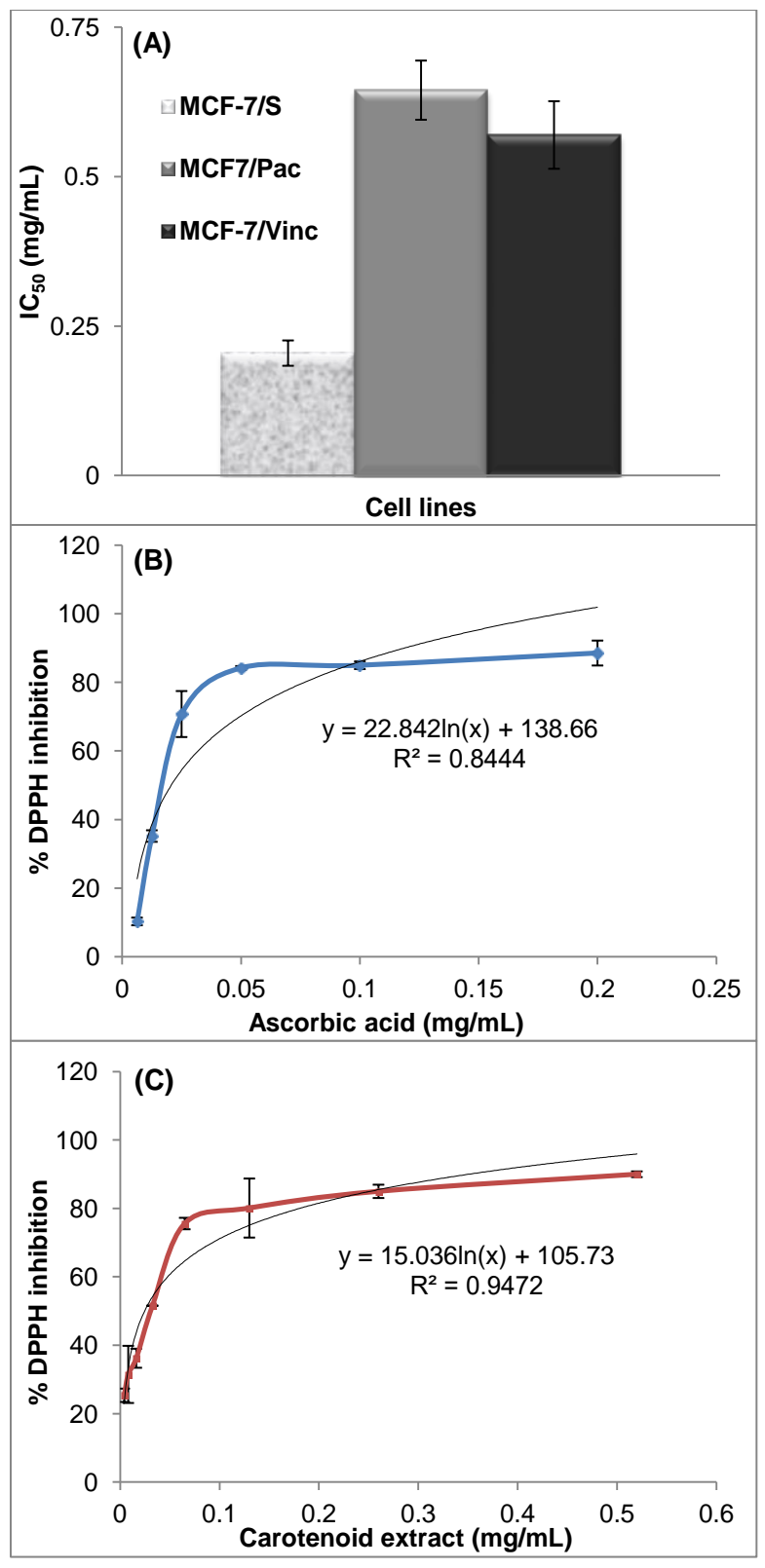

Figure 3. Cytotoxicity and antioxidant properties of carotenoids. (A) $\mathrm{IC}_{50}$ values of carotenoid extract on cell lines $(p<0.05)$; $(\mathbf{B})$ and $(\mathbf{C})$ are the DPPH scavenging activity of ascorbic acid and carotenoid extract, respectively $(\mathrm{p}<0.05)$.

\begin{tabular}{lccc}
\hline MCF-7 Cells & Drug + extract & $\begin{array}{c}\text { FIX } \pm \text { SD } \\
(\boldsymbol{p}<\mathbf{0 . 0 5})\end{array}$ & Interaction \\
\hline Paclitaxel R. & Paclitaxel + Carotenoid extract & $5.76 \pm 0.12$ & Antagonistic \\
Vincristine R. & Vincristine + Carotenoid extract & $3.78 \pm 0.12$ & Antagonistic \\
\hline
\end{tabular}

\subsection{Anti-Oxidant Capacity of Bacterial Carotenoid Extract}

Free radical scavenging activity of carotenoid extract was determined by calculating the DPPH clearance effect of carotenoids. The logarithmic equation of the DPPH\% inhibition vs L-ASA $(\mathrm{mg} / \mathrm{mL})$ graph was $\mathrm{y}=22.842 \ln (\mathrm{x})+138.66$ and that of DPPH inhibition vs carotenoid extract $(\mathrm{mg} / \mathrm{mL})$ graph was $\mathrm{y}=15.036 \ln (\mathrm{x})+105.73$ 
(Figure 3). The anti-oxidant capacities of the ascorbic acid (L-ASA) and bacterial carotenoids were found by putting the value 50.00 instead of $y$ in the equations and the result was expressed as $50 \%$ inhibitory concentration $\left(\mathrm{IC}_{50}\right)$. It was found that $R$. sphaeroides carotenoid extract inhibits the $50 \%$ of DPPH at a concentration of $25 \mu \mathrm{g} / \mathrm{mL}$. The antioxidant capacity of L-ASA $(21 \mu \mathrm{g} / \mathrm{mL})$ is about 0.84 -fold higher than that of carotenoids. That means bacterial carotenoid extract has very close antioxidant activity to that of L-ASA. Nie et al. (2016) cultured $R$. sphaeroides under microaerobic conditions for the rapid extraction of carotenoids and they found out that the isolated carotenoids had an $\mathrm{IC}_{50}$ value of $8.175 \mu \mathrm{g} / \mathrm{mL}$. This finding is different from the $\mathrm{IC}_{50}$ value obtained in the present study. This is most probably due to the culture conditions which affect the carotenoid composition of the bacterium such that reduced oxygen availability and light intensity was found to stimulate spheroidene production while downregulating the amount of spheroidenone (Yeliseev et al., 1996). It can be deduced from these results that culture conditions change the carotenoid composition in the bacterium and therefore the antioxidant capacity is also changed. The antioxidant capacity of a natural carotenoid or a natural phytochemical can also be exhibited as ascorbic acid equivalent antioxidant capacity (AEAC) as described previously (Jambun et al., 2018). AEAC of bacteria carotenoid extract was found to be $84 \mathrm{~g} \mathrm{~L}$ ASA/100 g bacterial carotenoids. According to the literature and previous findings, plant carotenoids, that have antioxidant activity, reverse drug resistance successfully (Molnár et al., 2004; Kars et al., 2008). Consequently, R. sphaeroides can also be considered as a promising natural source for carotenoid which may be a potential antioxidant or protective agent. Especially, the property of bacterial carotenoid being non-toxic to the cells makes it a valuable antioxidant and it also increases its biotechnological and medical uses.

\section{Conclusion}

Coloring agents, with antioxidant activities from natural sources, have a big demand in market. Therefore, intense investigation is needed to meet the natural carotenoid demand. In this regard, photosynthetic bacteria constitute important natural sources for carotenoids. They are nonpathogenic and can be cultured in cost efficient biotechnological bioprocesses. In the present study, significant amount of carotenoid was obtained from a photosynthetic bacterium $R$. sphaeroides by valorizing sugar beet molasses and its potential uses were evaluated. In this aspect, this study possesses all stages (upstream, downstream and product application) of a biotechnological bioprocess. A very high yield (80.69 mg carotenoid/g dry cell weight) was obtained by carefully selecting the culture conditions. Upon application of carotenoid extract on resistant MCF-7 cell lines, it was found that bacterial carotenoid extract did not diminish the viability of the cells. When the interaction of extract with microtubule inhibitor drugs which were paclitaxel and vincristine was considered, it was found out that carotenoid extract did not act synergistically with drugs. The carotenoid extract had antagonistic effects when applied in combination with the drugs paclitaxel and vincristine. According to literature and previous findings, plant carotenoids were found to reverse drug resistance successfully (Kars et al., 2008; Molnar et al., 2009). Since this total carotenoid extract did not exhibit antiproliferative effect on both sensitive and resistant breast cancer cells and it possesses a considerable antioxidant effect with an $\mathrm{IC}_{50}$ value of $25 \mu \mathrm{g} / \mathrm{mL}$ on singlet oxygen radicals especially, the bacterial carotenoids could be suggested to be assessed as a potential protecting and MDR modulating agent. Its MDR modulating function is needed to be revealed by resolving any effects on reversal of P-glycoprotein function. In future studies, the use of bacterial carotenoids as drug resistance modulator will further be investigated in addition to their medical use as natural antioxidant.

\section{Acknowledgement}

The support from The Scientific and Technological Research Council of TURKEY (Project No:110T552) was acknowledged gratefully. We would like to thank Prof. Dr. Samuel Kaplan (The University of Texas Health Science Center at Houston) for giving permission to use carotenoid images. Konya Şeker San. ve Tic. A.Ş. is acknowledged for providing molasses.

\section{References}

Aksu, Z. and Eren, A.T., 2005. Carotenoids Production by the Yeast Rhodotorula mucilaginosa: Use of Agricultural Wastes as a Carbon Source. Process Biochemistry, 40, 2985-2991.

Armstrong, A.G., 1994. Eubacteria Show Their True Colors: Genetics of Carotenoid Pigment Biosynthesis from Microbes to Plants. Journal of Bacteriology, 176, 4795-4802. 
Carvalho, L.M.J., Gomes, P.B., Godoy, R.L.O., Pacheco, S., Monte, P.H.F., Carvalho, J.L.V., Nutti, M.R., Neves, A.C.L., Vieira, A.C.R.A. and Ramos, S.R.R., 2012. Total Carotenoid Content, $\alpha$-Carotene and $\beta$-Carotene, of Landrace Pumpkins (Cucurbita moschata Duch): A Preliminary Study. Food Research International, 47, 337-340.

Diouf, P.N., Stevanovic, T. and Cloutier, A., 2009. Antioxidant Properties and Polyphenol Contents of Trembling Aspen Bark Extracts. Wood Science and Technology, 43, 457-470.

Fong, W.F., Wang, C., Zhu, G.Y., Leung, C.H., Yang, M.S. and Cheung, H.Y., 2007. Reversal of Multidrug Resistance in Cancer Cells by Rhizoma alismatis Extract. Phytomedicine, 14, 160-165.

Fraser, J.N., Hashimoto, H. and Cogdell, J.R., 2001. Carotenoids and Bacterial Photosynthesis: The Story So Far. Photosynthesis Research, 70, 249256.

Gu, Z., Chen, D., Han, Y., Chen, Z. and Gu, F., 2008. Optimization of Carotenoids Extraction from Rhodobacter sphaeroides. LWT-Food Science and Technology, 41, 1082-1088.

Jambun, D.D., Ong, K.S., Lim, Y.Y., Tan, J.B.L., Lee, W.L., Muhamad, A., Yap, S.W. and Lee, S.M., 2018. Antioxidant Properties of Etlingera pubescens, an Edible Ginger Plant Endemic to Borneo. Food Bioscience, 25, 44-51.

Joshi, H.M. and Tabita, F.R., 1996. A Global Two Component Signal Transduction System That Integrates the Control of Photosynthesis, Carbon Dioxide Assimilation, and Nitrogen Fixation. Proceedings of the National Academy of Sciences, 93, 14515-14520.

Kars, G. and Alparslan, Ü., 2013. Valorization of Sugar Beet Molasses for the Production of Biohydrogen and 5-Aminolevulinic Acid by Rhodobacter sphaeroides O.U. 001 in a Biorefinery Concept. International Journal of Hydrogen Energy, 38, 14488-14494.

Kars, G. and Gündüz, U., 2010. Towards a Super $\mathrm{H}_{2}$ Producer: Improvements in Photofermentative Biohydrogen Production by Genetic Manipulations. International Journal of Hydrogen Energy, 35, 6646-6656.

Kars, G., Gündüz, U., Yücel, M., Rakhely, G., Kovacs, K.L. and Eroğlu, İ., 2009. Evaluation of Hydrogen Production by Rhodobacter sphaeroides O.U. 001 and Its hupSL Deficient Mutant Using Acetate and Malate as Carbon Sources. International Journal of Hydrogen Energy, 34, 2184-2190.
Kars, M.D., İşeri, O.D., Gündüz, U. and Molnár, J., 2008. Reversal of MDR by Synthetic and Natural Compounds in Drug Resistant MCF-7 Cell Lines. Chemotherapy, 54, 194-200.

Kwon, S.Y., Jiang, S.N., Zheng, J.H., Choy, H.E. and Min, J.J., 2014. Rhodobacter sphaeroides, a Novel Tumor-Targeting Bacteria That Emits Natural Near-Infrared Fluorescence. Microbiology and Immunology, 58, 172-179.

Lang, H.P., Cogdell, R.J., Takaichi, S. and Hunter, C.N., 1995. Complete DNA Sequence, Specific Tn5 Insertion Map, and Gene Assignment of the Carotenoid Biosynthesis Pathway of Rhodobacter sphaeroides. Journal of Bacteriology, 177, 2064-2073.

Li, C., Swofford, C.A. and Sinskey, A.J., 2020. Modular Engineering for Microbial Production of Carotenoids. Metabolic Engineering Communications, 10, e00118.

Macias-Sanchez, M.D., Mantell, C., Rodriguez, M., Martinez de la Ossa, E., Lubián, L.M. and Montero, O., 2005. Supercritical Fluid Extraction of Carotenoids and Chlorophyll a from Nannochloropsis gaditana. Journal of Food Engineering, 66, 245-251.

Menon, V. and Rao, M., 2012. Trends in Bioconversion of Lignocellulose: Biofuels, Platform Chemicals \& Biorefinery Concept. Progress in Energy and Combustion Science, $38,522-550$.

Molnár, J., Gyemant, N., Mucsi, I., Molnár, A., Szabo, M., Körtvélyesi, T., Varga, A., Molnár, P. and Tóth, G., 2004. Modulation of Multidrug Resistance and Apoptosis of Cancer Cells by Selected Carotenoids. In vivo, 18, 237-244.

Molnar, J., Kars, M.K., Gündüz, U., Engi, H., Schumacher, U., Van damme, E.J., Peumans, W.J., Makovitzky, J., Gyémánt, N. and Molnar, P., 2009. Interaction of Tomato Lectin with ABC Transporter in Cancer Cells: Glycosylation Confers Functional Conformation of P-gp. Acta Histochemica, 111, 329-333.

Nie, X., Xiao, C., Zhang, L., Zhao, Y., Liu, X., Wang, J., Tang, Y., Liu, Y., Zhao, Z. and Pan, Y., 2016. Rapid Production of Natural Carotenoids from Rhodobacter sphaeroides. Advance Journal of Food Science and Technology, 11, 800-804.

O'driscoll, L. and Clynes, M., 2006. Molecular Markers of Multiple Drug Resistance in Breast Cancer. Chemotherapy, 52, 125-129.

Oelze, J. and Klein, G., 1996. Control of Nitrogen Fixation by Oxygen in Purple Nonsulfur 
Bacteria. Archives of Microbiology, 165, 219225.

Saini, R.K. and Keum, Y.S., 2018. Carotenoid Extraction Methods: A Review of Recent Developments. Food Chemistry, 240, 90-103.

Saklani, A. and Kutty, S.K., 2008. Plant-Derived Compounds in Clinical Trials. Drug Discovery Today, 13, 161-171.

Sasaki, K., Watanabe, M., Suda, Y., Ishizuka, A. and Noparatnaraporn, N., 2005. Applications of Photosynthetic Bacteria for Medical Fields. Journal of Bioscience and Bioengineering, 100, 481-488.

Shneour, E.A., 1962. Carotenoid Pigment Conversion in Rhodopseudomonas spheroids. Biochimica et Biophysica Acta, 62, 534-540.

Squina, F.M., Yamashita, F., Pereira, J.L. and Mercadante, A.Z., 2002. Production of Carotenoids by Rhodotorula rubra and $R$. glutinis in Culture Medium Supplemented with Sugar Cane Juice. Food Biotechnology, 16, 227235.

Takayama, K., Qureshi, N., Beutler, B. and Kirkland, T.N., 1989. Diphosphoryl Lipid a from Rhodopseudomonas sphaeroides ATCC 17023 Blocks Induction of Cachectin in Macrophages by Lipopolysaccharide. Infection and Immunity, 57, 1336-1338.

Teng, Y.N., Sheu, M.J., Hsieh, Y.W., Wang, R.Y., Chiang, Y.C. and Hung, C.C., 2016. $\beta$-Carotene Reverses Multidrug Resistant Cancer Cells by Selectively Modulating Human P-Glycoprotein Function. Phytomedicine, 23, 316-323.
Ugocsai, K., Varga, A., Molnar, P., Antus, S. and Molnar, J., 2005. Effects of Selected Flovanoids and Carotenoids on Drug Accumulation and Apoptosis Induction in Multidrug-Resistant Colon Cancer Cells Expressing MDR1/LRP. In vivo, 19, 433-438.

Varmira, K., Habibi, A., Moradi, S. and Bahramian, E., 2018. Experimental Evaluation of Airlift Photobioreactor for Carotenoid Pigments Production by Rhodotorula rubra. Romanian Biotechnological Letters, 23, 13843-13852.

Wong, H.L., Wu, X.Y. and Bendayan, R., 2009. Multidrug Resistance in Solid Tumor and Its Reversal, in: Lu, Y., Mahato, R. (Eds), Pharmaceutical Perspectives of Cancer Therapeutics. Springer, New York, pp.121-148.

Yeliseev, A.A., Eraso, J.M. and Kaplan, S., 1996. Differential Carotenoid Composition of the B875 and B800-850 Photosynthetic Antenna Complexes in Rhodobacter sphaeroides 2.4.1: Involvement of Spheroidene and Spheroidenone in Adaptation to Changes in Light Intensity and Oxygen Availability. Journal of Bacteriology, 178, 5877-5883.

Yeliseev, A.A. and Kaplan S., 1997. Anaerobic Carotenoid Biosynthesis in Rhodobacter sphaeroides 2.4.1: $\mathrm{H}_{2} \mathrm{O}$ is a Source of Oxygen for the 1-Methoxy Group of Spheroidene but not for the 2-Oxo Group of Spheroidenone. FEBS Letters, 403, 10-14.

Zhao, Y., Guo, L., Xia, Y., Zhuang, X. and Chu, W., 2019. Isolation, Identification of CarotenoidProducing Rhodotorula sp. from Marine Environment and Optimization for Carotenoid Production. Marine Drugs, 17, 161. 